\title{
The Sounding Museum: Two Weeks in Alert BaY
}

\author{
Hein Schoer, MA \\ Research Group Arts in Society, Fontys School of the Arts, Tilburg (NL) / Maastricht University (NL), h.schoer@fontys.nl \\ for more information: www.fontys.edu/artsinsociety, www.gruenrekorder.de, www.nonam.ch, www.auditorium-mundi.com
}

\section{EXPOSITION: COMING TO IN ALERT BAY}

\section{A raven croaks.}

I hear a faint broadband noise, not static but gently varying in volume, centre frequency and Zwicker's parameters. At first there are only short blows that enter my consciousness, but as I regain awareness, it becomes a constant, swooshing sound, that, as I realise after a moment of malorientation, arrives at my ears mainly from the half-open window of my room at the Alert Bay Lodge facing the forest behind it.

It's still dark, so I keep lying and listening. The ocean waves manage to escape the masking grip of the wind in the trees. I can hear them very well now; although their frequency band is not that different from the wind, the internal structure of the waveform allows my brain to separate them from one another. I rub the fatigue out of my eyes, slip into my clothes, grab my gear, and head for the opening in the middle of the forest of Cormorant Island Ecological Park.

The spirits of the skies are with me tonight, I think, as the wind stops to blow and leaves nothing but silence. I had been up here late in the evening, and had made a good quarter of an hour of nice ambience recordings, the dominant sound had been wind, but for the morning atmo I prefer a low noisefloor to be able to capture the awaking bugs and birds. With the whole island still asleep the dying wind leaves me in peaceful quiet (except for a hint of tinnitus).

\section{$1^{\text {ST }}$ WORLD/MOVEMENT: THE NATURAL SOUNDSCAPE}

I have come to Alert Bay, BC (British Columbia) in the course of my research project "The Sounding Museum", within which I look at (and listen to) the production and presentation of cultural soundscapes.

The crows are the first to come alive, some distant, some closer to my recording position, and all around the place, making it evident that they are the dominant species in the sonic layer of the local ecosystem. Raven may still be the trickster lord of the spirit realm, but he is definitely not alone in the animal kingdom. Next to his croaks a woodpecker knocks, and a number of smaller birds, the names of which I do not know, claim their territory. I wish I had the keenness of the Kaluli of Bosavi who Steven Feld visited, then I could attach names and meaning to their song. Luckily I haven't come here for ornithological studies.

At the inhabited end of the island there also seems to be some early bird, as I can hear a first car engine going off.
As the sun rises above the trees, I turn to the stony beach. The nuthatch that had accompanied me with its sharp highpitched short yelps now has to share the acoustic space with numerous seabirds, above all seagulls, but also some duckor gooselike critters.

Now I have to wait for rain, as no $\mathrm{BC}$ soundscape can be complete without the constant rain that covers all the land and the sea with a veil of thin grey braids.

\section{$2^{\mathrm{ND}}$ WORLD/MOVEMENT: THE ARTIFICIAL SOUNDSCAPE}

Despite its small population Alert Bay is one of the cultural centres of the Kwakwawa'wakw, not the least due to the U'mista Cultural Society that is located here, and, as claimed by Bruce Alfred, one of the few who still possess the knowledge and the skill to create bentwood artwork, the heart of woodcarving at the Pacific Northwest Coast.

The natural beach atmo mixes with an Alert Bay ambience. Now the day has really started, the town is getting busy. I hear cars passing, harbour activity, and the starlings and crows in front of the U'mista Cultural Centre. I never get to catch the voice of the bald eagle. I see one sitting on a pole in the water one evening; he would stare at me for an hour, and I would stare back, shotgun ready, but he wouldn't talk.

Sometime around the eagle incident I finally realise that it would be folly to try and create a representational soundscape covering all there is to Northwest Coast indigenous culture and wildlife. What I make instead is a very personal, locally and temporally constricted composition, presenting the impressions of my two-week stay at Alert Bay, featuring the individuals I meet, the events I witness, and the atmospheres I feel in nature and around people.

I had spent some time with Bruce Alfred in the carvers' workshop the other day, made recordings of woodworking tools in action, and a long interview about the difficulty of finding apprentices to continue with the traditional arts, and how the old ways can help the young to find their place in the world. Now I am at Beau Dick's house, recording Beau bucking some block of wood with a handsaw and hollowing the backside of a small totem pole. We go inside, where I just sit for a good hour to talk and listen and watch the carvers at work, while the microphone patiently records.

Being in this busy workshop atmosphere offers a beautiful insight into the many facets and layers of a living culture with such ancient origins. The masks talk of a mythic past and tradition, and some of them will be used in the spirit of that tradition. Others are carved to make a living, exploiting the Man's craving for exoticism in his living room. 


\section{$3^{\mathrm{RD}}$ WORLD/MOVEMENT: THE HUMAN SOUNDSCAPE}

At the T'lisalagi'lakw Native School great efforts are made to counter the effects of the many decades of cultural deracination. Teachers like Sandi Willie, Lina Nichols, and Vera Newman not only teach the children how to read, write, count, and about the different parts of the nervous system, there are also daily classes on traditional song and dance, and Kwakwala language class.

I present them as I see (hear) them, not focussing exclusively on the "exotic" parts of the Alert Bay Soundscape, but rather trying to provide the whole picture of my stay, which included science class and a steak sandwich dinner (didn't record that, though) at the Nimpkish Pub just as much as a Hamatsa initiation (didn't include that, because it's not approved for public presentation) at a potlatch.

The children are obviously having fun, but also a hard time catching up. To me it seems doubtful if they will ever fully master this language, as they are growing up with English at home and everywhere else; Kwakwala is not spoken in everyday conversation anywhere, the residential school system has taken care of that.

For us the girls dance in full regalia, with their family crests on their button blankets. We witness four traditional dances: Ladies' Professional, Salmon Dance, Paddle Dance, and a dance with red shawls. I decide to keep the hum of the ventilation system in the mix, I won't try to remove it with my denoising tools; unlike the hardware noise resulting from a poor signal-to-noise ratio, it is part of the original soundscape, annoying maybe, but genuine.

\section{$4^{\mathrm{TH}}$ WORLD/MOVEMENT: \\ THE CULTURAL SOUNDSCAPE \& THE SPIRIT WORLD}

Potlatch is the most important ceremonial festivity in Northwest Coast culture with deep religious and ritual meaning; dances, songs, masks, and treasures are presented to the audience that is provided for with vast amounts of food and presents. Fiercely challenged by the arrival of Europeans, the culture of the Northwest Coast people had been almost wiped out, potlatch as central expression of this culture was prohibited in 1884 . With the ban officially lifted around 50 years ago, the Natives continue to bring back the original spirit of potlatching to life in a contemporary form.

Wa (William Wasden jr.) has invited me to join him at Chief Robert Duncan's potlatch at Campbell River, so the next morning sees us at the Bighouse at nine o'clock. Mourning songs have to be sung before noon, otherwise they will invite the spirits to come and prey on more people.

I will not attempt to try and describe what's happening, one has to be there, to watch and listen, and even then one can only get a vague idea of what it all means to the people.
The feast will go on until past midnight, countless dances and songs, a Hamatsa initiation, a clown's act, the chief will open his box of treasures, we will all eat and drink and have the stripes of red cedar bark around our heads, many speeches will be held, Wa will spread the eagle down... I feel I am being sucked into a wall of sound that soon is all around me. I begin to really understand what Beau Dick meant, when he explained how you get caught up in the music and the sound and "something takes over."

And indeed it does. Engulfed by the hypnotising power of voice and beat, I wander from the dim confinement of the bighouse, the music begins to blur and before I know it, I am in the Spirit World. From the mists of my limbic forest I hear a rejoicing fun dance cheer, the chief has shown his greatness, his people are glad. But they sink into the mists and I realise I am in the animal kingdom. Before I know it, mighty Thunderbird flies over my head and takes me even farther into the mist. I am thinking of using a couple of drum beats from the recording to mimic the thunder of his wings by means of some convolution reverb plug-ins.

The animals have stayed behind, the curtain is lifted to show the spirits lined up to pay me a visit (or do I visit them? After all, it is their world, and I am the intruder). There is tame Bukwas, there is Nutslala the firedancer, and Nutslama, screaming "Wi!Wi!Wi!", and he's running around, he's laughing, and he's throwing snot at me. There is Xwixwi, his tongue is sticking out of his mouth and his eyes are bulgy, and of course Dzunuqwa, coming out of the bushes with her "hu-hu" to scoop me into her basket. As I hear Dzunuqwi coming from the sea with his bubbling voice - his throat is filled with water, and he's got seaweed all over him - I notice that the soundscape becomes clearer again.

\section{REPRISE: DOWN TO EARTH}

The day ends in the cosy atmosphere of Woss Lake cabin, with a fine share of grilled, smoked, sweetened and teriyaki sockeye, halibut, prawns and eulachon (no, that will be at the seafood dinner with the totem poll restoration workshop guys, but the dinner at Woss Lake is no less opulent, just instead of the halibut we have hamburgers and potato salad), Wa singing children songs and the family talking.

U'melth, the Raven, croaks one last time for me, spreads his wings and flies away. Tomorrow I will be on my plane home.

It finally starts to rain.

\section{ACKNOWLEDGEMENTS}

I wish to thank the people of Alert Bay and the U'mista for sharing their world with me: William Wasden jr., Andrea Sanborn, Pewi Alfred, Marcus Alfred, Bruce Alfred, Beau Dick, Sandi Willie, Lina Nichols, Vera Newman, Sean Whonnock and many others, my endorsers and collaborators at fontys, NONAM, Maastricht University and elsewhere. Dedicated to Richard Schuckmann and Andrea Sanborn. 